Jurnal Tropicrops

Vol 3 No. 2, Agustus 2020: 8-14

ISSN: 2615-7012

\title{
UJI KOSENTRASI EC (ELECTRO CONDUCTIVITY) \\ DAN TINGKAT NAUNGAN \\ PADA HASIL DAN PERTUMBUHAN TANAMAN \\ SAWI PAKCOY (Brassica chinensis L.) PADA GREENHOUSE \\ PARANET
}

\author{
*Wiharyanti Nur Lailiyah ${ }^{1}$, Sa'idah Luthfiyah ${ }^{2}$ \\ ${ }^{1,2}$ Dosen Program Studi Agroteknologi, Fakultas Pertanian \\ Universitas Muhammadiyah Gresik \\ Jln Sumatra No. 101 GKB, Gresik - Jawa Timur 61121 \\ e-Mail : wiharyanti@gmail.com
}

\begin{abstract}
ABSTRAK
Sistem budidaya tanaman secara hidroponik dapat menjadi salah satu solusi bagi pengembangan tanaman buah dan sayur dengan berbagai kelebihan dibandingkan sistem pertanian konvensional. Budidaya tanaman sayuran seperti sawi dengan sistem hidroponik dianggap lebih efisien dalam penggunaan air dan tanah. Selain itu budidaya tanaman sayuran dengan cara hidroponik dapat memperbaiki kualitas dari hasil tanaman karena hasil panen dari tanaman tidak kotor karena tanah dan bebas dari pestisida kimia. Sistem hidroponik sangat bergantung pada larutan nutrisi yang digunakan. Penggunaan nutrisi yang berlebihan dapat menyebabkan keracunan pada tanaman. Sedangkan jika penggunaan nutrisi terlalu sedikit maka dapat menyebabkan terhambatnya pertumbuhan tanaman. Tujuan dari penelitian ini yaitu untuk mengetahui kosentrasi nutrisi yang sesuai pada tanaman sawi pakcoy. Penelitian ini menggunakan rancangan acak lengkap yang terdiri dari 6 perlakuan dan 4 ulangan, perlakuannya yaitu P0: Tanpa Nutrisi; P1: konsentrasi EC 0,5; P2: konsentrasi EC 1,0; P3: konsentrasi EC 1,25; P4: konsentrasi EC 1,5; P5: konsentrasi EC 2,0. Data pengamatan yang diperoleh dianalisis dengan menggunakan analisis ragam (uji $\mathrm{F}$ ) pada taraf 5\%. Bila hasil pengujian diperoleh perbedaaan yang nyata maka dilanjutkan dengan uji perbandingan antar perlakuan dengan menggunakan Beda Nyata Terkecil (BNT) pada taraf 5\%.
\end{abstract}

Kata kunci: Hidroponik, Pakcoy dan EC (Electrical Conductivity)

\section{PENDAHULUAN}

Pertumbuhan perekonomian di Indonesia pada sektor pertanian mengalami penurunan pada kuartal pertama pada tahun 2016 dibandingka pada tahun 2015.dari data Badan Pusat Statistika menunjukkan bahwa angka pertumbuhan pertanian di Indonesia mengalami penurunan sebesar $1,85 \%$ dibandingkan dengan angka pertumbuhan pertanian di Indonesia pada tahun 2015 yaitu mencapai 4,03\%. Terjadinya penurunan sektor pertanian berdampak serius pada pertumbuhan perekonomian di Indonesia mengingat sektor perdagangan Indonesia masih banyak yang bergantung pada sektor pertanian. Menurunnya pertumbuhan pertanian di Indonesia ini salah satunya diakibatkan oleh efek dari perubahan iklim. Selain perubahan iklim menurunnya pertumbuhan pertanian di Indonesia pada saat ini sebagian besar beralih fungsi lahan khususnya di pulau jawa (Gevisioner, Rudi Febriamansyah, Ifdal, Suardi Tarumun, 2015). 
Jurnal Tropicrops Vol 3 No. 2, Agustus 2020: 21-25

Seiring dengan berkembangnya waktu, lahan pertanian di Indonesia sebagian besar sudah beralih fungsi dimana sudah tidak lagi menjadi lahan pertanian melainkan sebagai perumahan, perusahaan, mall dan lain-lain. Dengan demikian, budidaya tanaman dengan menggunakan sistem hidroponik dianggap sebagai alternatif budidaya tanaman yang sangat menguntungkan dan diminati oleh semua kalangan. Budidaya tanaman sayurang dengan menggunakan sistem hidroponik dianggap sebagai budidaya tanaman yang sederhana dan sangat mudah untuk dibudidayakan. Budidaya dengan sistem ini tidak memerlukan lahan yang luas sehingga sangat efektif untuk menghadapi permasalahan pada saat ini. Dengan menggunakan sistem hidroponik maka dengan sebidang lahan akan menghasilkan tanaman yang tinggi karena dengan sistem ini model budidaya tanaman bisa dibuat susunan tanaman (Munoz, 2010).

Budidaya tanaman dengan sistem hidroponik sebagian besar dilakukan di Greenhouse. Secara umum green house dapat didefinisikan sebagai bangun kontruksi dengan atap tembus cahaya yang berfungsi memanipulasi kondisi lingkungan agar tanaman di dalamnya dapat berkembang optimal. Manipulasi lingkungan ini dilakukan dalam dua hal, yaitu menghindari kondisi lingkungan yang tidak dikehendaki dan memunculkan kondisi lingkungan yang dikehendaki. Dengan demikian, budidaya tanaman dapat dilakukan sepanjang tahun tanpa menyesuaikan dengan kondisi lingkungan seperti,efek dari perubahan iklim (Lingga. 2003).

Sistem hidroponik sangat bergantung pada larutan nutrisi yang digunakan. Penggunaan nutrisi yang berlebihan dapat menyebabkan keracunan pada tanaman. Sedangkan jika penggunaan nutrisi terlalu sedikit maka dapat menyebabkan terhambatnya pertumbuhan tanaman. Konsentrasi penggunaan nutrisi tanaman dapat diukur dengan menggunakan parameter EC (Electrical Conductivity).
Menurut Sutiyoso, EC adalah kemampuan untuk menghantarkan ion-ion listrik yang terkandung dalam larutan nutrisi ke akar tanaman EC merupakan parameter yang menunjukkan konsentrasi ion-ion yang terlarut dalam larutan nutrisi. Tinggi rendahnya EC dalam larutan nutrisi memengaruhi metabolisme tanaman, yaitu kecepatan fotosintesis tanaman, aktivitas rezim dan potensi penyerapan ion-ion larutaneh akar tanaman (Barbosa, 2015)

\section{METODE}

Penelitian ini dilakukan di Greenhouse masjid Baitul Muhti di Dukuh Mulyomukti, Kecamatan Pakal, Surabaya. penelitian ini dilaksanakan pada bulan Maret-Aprili 2020. Alat yang digunakan dalam penelitian ini berupa kamera, penggaris, mesin bor, dan peralatan tulis lainnya. Untuk kamera digunakan sebagai dokumentasi yang dapat menunjang dan melengkapi data di lapangan. Bahan-bahan yang digunakan ialah pipa, netpot, benih sawi dan nutrisi.

Penelitian ini menggunakan rancangan acak lengkap yang terdiri dari 6 perlakuan dan 4 ulangan, perlakuannya yaitu P0: Tanpa Nutrisi; P1: konsentrasi EC 0,5; P2: konsentrasi EC 1,0; P3: konsentrasi EC 1,25; P4: konsentrasi EC 1,5; P5: konsentrasi EC 2,0. Data pengamatan yang diperoleh dianalisis dengan menggunakan analisis ragam (uji F) pada taraf 5\%. Bila hasil pengujian diperoleh perbedaaan yang nyata maka dilanjutkan dengan uji perbandingan antar perlakuan dengan menggunakan Beda Nyata Terkecil (BNT) pada taraf $5 \%$.

\section{HASIL DAN PEMBAHASAN}

Pertumbuhan tanaman ialah suatu proses kehidupan tanaman pada habitatnya yang menghasilkan pertambahan ukuran, bentuk atau volume. Komponen pertumbuhan tanaman sawi pakcoy seperti tinggi tanaman dan jumlah daun ialah komponen yang harus diamati untuk mengetahui bahwa suatu tanaman telah mengalami perubahan pertumbuhan. Pertumbuhan ini sangat dipengaruhi oleh 
nutrisi yang diberikan dan kondisi lingkungan dimana tanaman tersebut tumbuh atau dibudidayakan.

Tabel 1. Rata-rata Tinggi Tanaman Sawi Pakcoy pada Berbagai Kosentrasi EC

\begin{tabular}{cccccc}
\hline \multirow{2}{*}{ Perlakuan } & \multicolumn{5}{c}{$\begin{array}{c}\text { Tinggi Tanaman per Individu bibit Tanaman (cm) } \\
\text { pada Umur Pengamatan }\end{array}$} \\
\cline { 2 - 6 } & $\mathbf{1}$ & $\mathbf{2}$ & $\mathbf{3}$ & $\mathbf{4}$ & $\mathbf{5}$ \\
\hline P0 & 3,63 & 10,63 & $17,75 \mathrm{~b}$ & $23,25 \mathrm{c}$ & 25,50 \\
P1 & 3,50 & 10,75 & $18,75 \mathrm{ab}$ & $24,00 \mathrm{bc}$ & 25,50 \\
P2 & 3,75 & 10,63 & $18,75 \mathrm{ab}$ & $24,75 \mathrm{~b}$ & 26,00 \\
P3 & 3,63 & 10,63 & $18,50 \mathrm{ab}$ & $24,50 \mathrm{~b}$ & 26,00 \\
P4 & 3,63 & 10,75 & $19,50 \mathrm{a}$ & $26,00 \mathrm{a}$ & 26,50 \\
P5 & 3,63 & 10,63 & $19,00 \mathrm{a}$ & $25,75 \mathrm{a}$ & 26,00 \\
\hline BNT 5\% & tn & tn & 1,01 & 0,88 & tn \\
\hline
\end{tabular}

Keterangan: P0: Tanpa Nutrisi; P1: konsentrasi EC 0,5; P2: konsentrasi EC 1,0; P3: konsentrasi EC 1,25; P4:konsentrasi EC 1,5; P5: konsentrasi EC 2,0. Bila didampingi huruf yang sama pada umur dan kolom yang sama menunjukkan tidak beda nyata berdasarkan uji BNT $5 \%$; tn=tidak nyata

Tabel 2. Rata-rata Jumlah Daun Sawi Pakcoy pada Berbagai Kosentrasi EC

\begin{tabular}{cccccc}
\hline \multirow{2}{*}{ Perlakuan } & \multicolumn{5}{c}{$\begin{array}{c}\text { Jumlah Daun per Individu bibit Tanaman } \\
\text { pada Umur Pengamatan (MST) }\end{array}$} \\
\cline { 2 - 6 } & $\mathbf{1}$ & $\mathbf{2}$ & $\mathbf{3}$ & $\mathbf{4}$ & $\mathbf{5}$ \\
\hline P0 & 1,25 & 3,25 & 7,25 & 11,25 & 14,25 \\
P1 & 1,50 & 3,25 & 7,50 & 11,50 & 14,25 \\
P2 & 1,25 & 3,00 & 7,25 & 11,25 & 14,50 \\
P3 & 1,50 & 3,50 & 7,50 & 11,50 & 14,75 \\
P4 & 1,50 & 3,50 & 8,50 & 11,75 & 15,00 \\
P5 & 1,50 & 3,25 & 7,75 & 11,50 & 14,75 \\
\hline BNT 5\% & tn & tn & 0,79 & tn & tn \\
\hline
\end{tabular}

Keterangan: P0: Tanpa Nutrisi; P1: konsentrasi EC 0,5; P2: konsentrasi EC 1,0; P3: konsentrasi EC 1,25; P4:konsentrasi EC 1,5; P5: konsentrasi EC 2,0. Bila didampingi huruf yang sama pada umur dan kolom yang sama menunjukkan tidak beda nyata berdasarkan uji BNT $5 \%$; tn=tidak nyata

Pada tanel 1 dan 2 menunjukkan bahwa dengan perlakuan pemberian nutrisi dengan nilai EC yang berbeda tidak memberikan pengaruh yang nyata pada perlakuan tinggi tanaman pada umur 1,2 dan 5 minggu setelah tanam dan memberikan pengaruh yang nyata pada umur tanaman 3 dan 4 minggu setelah tanam. Sedangkan pada jumlah daun tidak memebrikan pengaruh yang nyata pada waktu umur pengamatan $1,2,4$ dan 5 minggu setelah tanam dan memberikan pengaruh yang nyata pada umur pengamatan 3 minggu setelah tanam. Hasil tertinggi terdapat pada perlakuan perlakuan P4: konsentrasi EC 1,5 dan P5: konsentrasi EC 2,0 dibandingkan dengan perlakuan P0: tanpa menggunakan nutrisi.

Salah satu cara untuk memperoleh pertumbuhan tanaman yang baik adalah dengan cara pemupukan. Pemupukan merupakan suatu usaha penambahan unsurunsur hara dalam tanah yang dapat meningkatkan produksi kesuburan tanah dan mutu hasil tanaman. Pemberian pupuk yang kurang tepat baik jenis, dosis, waktu 
Lailiyah dan Sa'idah, Uji Konsentrasi EC .....

dan cara pemupukan yang digunakan akan menyebabkan tanaman terganggu, sehingga tanaman tersebut tidak dapat menghasilkan seperti apa yang diharapkan. Unsur N, P, dan $\mathrm{K}$ merupakan unsur-unsur esensial dalam jumlah yang cukup banyak (Istarofah, 2017). Menurut Parks dan Murray (2011), dalam sistem budidaya secara hidroponik perlu diberikan larutan nutrisi yang cukup, air, dan oksigen pada perakaran tanaman agar pertumbuhan tanaman baik.

Nugraha (2015), menyatakan bahwa di antara faktor-faktor yang mempengaruhi sistem produksi tanaman secara hidroponik, larutan nutrisi menjadi salah satu faktor penentu yang paling penting dalam menentukan hasil dan kualitas tanaman khususnya pada tanaman sawi. Penelitian ini dilakukan bertujuan untuk mengetahui pengaruh pertumbuhan dan hasil pada tanaman sawi dengan menggunakan sistem budidaya hidroponik. Pada budidaya tanaman secara hidroponik garam-garam mineral dilarutkan dalam air dengan komposisi tertentu. Campuran garam-garam mineral dan air ini biasa disebut larutan nutrisi.

Tabel 3. Rata-rata Komponen Hasil Diameter Bonggol, Bobot segar tanaman dan Bobot Segar Konsumsi Sawi Pakcoy pada Berbagai Kosentrasi EC

\begin{tabular}{cccc}
\hline Perlakuan & $\begin{array}{c}\text { Diameter } \\
\text { Bonggol } \\
(\mathbf{c m})\end{array}$ & $\begin{array}{c}\text { Bobot Segar } \\
\text { Total Tanaman } \\
(\mathbf{g} / \text { tan })\end{array}$ & $\begin{array}{c}\text { Bobot Segar } \\
\text { Konsumsi } \\
(\mathbf{g} / \text { tan })\end{array}$ \\
\hline P0 & 5,31 & 186,55 & 155,55 \\
P1 & 5,31 & 187,33 & 156,33 \\
P2 & 5,75 & 193,88 & 161,88 \\
P3 & 5,63 & 190,65 & 160,65 \\
P4 & 6,13 & 202,33 & 172,95 \\
P5 & 5,88 & 202,40 & 174,85 \\
\hline BNT 5\% & tn & 9,72 & 10,12 \\
\hline
\end{tabular}

Keterangan: P0: Tanpa Nutrisi; P1: konsentrasi EC 0,5; P2: konsentrasi EC 1,0; P3: konsentrasi EC 1,25; P4:konsentrasi EC 1,5; P5: konsentrasi EC 2,0. Bila didampingi huruf yang sama pada umur dan kolom yang sama menunjukkan tidak beda nyata berdasarkan uji BNT $5 \%$; th=tidak nyata

Pada tanel 3 menunjukkan bahwa dengan perlakuan pemberian nutrisi dengan nilai EC yang berbeda tidak memberikan pengaruh yang nyata pada perlakuan diameter bonggol. Sedangkan pada perlakuan bobot segar total tanaman dan bobot segar konsumsi memberikan pengaruh yang nyata. Hasil tertinggi terdapat pada perlakuan perlakuan $\mathrm{P} 4$ : konsentrasi EC 1,5 dan P5: konsentrasi EC 2,0 dibandingkan dengan perlakuan $\mathrm{P} 0$ : tanpa menggunakan nutrisi.

Menurut Lingga (2015), nutrisi yang diberikan pada tanaman harus dalam komposisi yang tepat. Bila kekurangan atau kelebihan, akan mengakibatkan pertumbuhan tanaman terganggu dan hasil produksi yang diperolehpun kurang maksimal. Pupuk hidroponik (larutan nutrisi hidroponik) mengandung semua nutrisi mikro dan makro dalam jumlah sesuai, berbeda dengan pupuk reguler (pupuk tanah). Selain itu, pupuk hidroponik juga bersifat lebih stabil dan cepat larut dalam air karena berada dalam bentuk lebih murni.

\section{KESIMPULAN}

Pemberian nutrisi dengan kosentrasi EC (Electrical Conductivity) yang berbeda dapat meningkatkan pertumbuhan tanaman pada kosentrasi EC 1,5 dan 2,0 dibandingkan dengan perlakuan tanpa pemberian nutrisi.

\section{DAFTAR PUSTAKA}

Barbosa. 2015, Comparison of Land, Water, and Energy Requirements of 
Lettuce Grown Using Hydroponic vs. Conventional Agricultural Methods, Int. J. Environ. Res. Public Health, ISSN 1660-4601 Basuki Rahmat. 2000. Dasar-dasar Usaha Budidaya Jamur. MAJI pblikasi. Bandung. 97 hal.

Gevisioner, Rudi Febriamansyah, Ifdal, Suardi Tarumun, 2015, J. Gizi Pangan, November 2015, 10(3): 233-240, Kualitas Konsumsi Pangan Di Daerah Defisit Pangan Provinsi Riau, ISSN 1978-1059

Istarofah, Zuchrotus Salamah. 2017. Pertumbuhan tanaman sawi hijau (Brassica juncea L.)dengan pemberian kompos berbahan dasar daun paitan (Thitonia diversifolia). Jurnal Bio-site. 3(1): 39-46.

Lingga. 2003. Hidroponik Bercocok Tanam Tanpa Tanah. Jakarta: Penebar Swadaya

Lingga, P. 2005. Hidroponik Bercocok Tanam Tanpa Tanah. Penebar Swadaya. Jakarta. Hal 80. Lingga, P. 2011. Hidroponik Bercocok Tanam Tanpa Tanah. Cetakan XXXII. Penerbit Penebar Swadaya. Jakarta.

Munoz, 2010, Hydropnics Home-based Vegetable Production System Manual, Inter-American Institute for Cooperation on Agriculture, Guyana

Munns, R. 2002. Comparative Physiology of Salt and Water Stress. Journal of Plant cell and environment. 2(5): 29250.

Nugraha, Rizqi Utami. 2015. Sumber Sebagai Hara Pengganti AB mix pada Budidaya Sayuran Daun Secara Hidroponik. J. Hort Indonesia 6 (1): 11- 19. April 2015.

Nugraha, R. U. 2014. Sumber Hara Sebagai Pengganti AB mix pada Budidaya Sayuran Daun Secara Hidroponik. Departemen Agronomi dan Holtikultura: Institut Pertanian Bogor. 